\title{
Characteristics of and outcomes for elderly patients with acute myocardial infarction: differences between females and males
}

This article was published in the following Dove Press journal:

Clinical Interventions in Aging

21 September 2016

Number of times this article has been viewed

\author{
Nguyen Dang Thang' \\ Björn Wilgot Karlson ${ }^{1,2}$ \\ Thomas Karlsson ${ }^{3}$ \\ Johan Herlitz ${ }^{1,4}$ \\ 'Department of Molecular and \\ Clinical Medicine, Sahlgrenska \\ University Hospital, Gothenburg, \\ ${ }^{2}$ AstraZeneca R\&D, Mölndal, ${ }^{3}$ Health \\ Metrics, Institute of Medicine, \\ Sahlgrenska Academy, University of \\ Gothenburg, Gothenburg, ${ }^{4}$ School \\ of Health Sciences, Research Centre \\ PreHospen, University of Borås, The \\ Pre-hospital Research Centre of \\ Western Sweden, Borås, Sweden
}

Objectives: This study analyzed age-adjusted sex differences among acute myocardial infarction (AMI) patients aged 75 years and above with regard to 7-year mortality (primary end point) and the frequency of angiograms and admission to the coronary care unit (CCU) as well as 1-year mortality (secondary end points).

Methods: A retrospective cohort study comprised 1,414 AMI patients (748 females and 666 males) aged at least 75 years, who were admitted to Sahlgrenska University Hospital in Gothenburg, Sweden, during two periods (2001/2002 and 2007). All comparisons between female and male patients were age adjusted.

Results: Females were older and their previous history included fewer AMIs, coronary artery bypass grafting procedures, and renal diseases, but more frequent incidence of hypertension. On the contrary, males had higher age-adjusted 7-year mortality in relation to females (hazard ratio [HR] 1.16 with corresponding 95\% confidence interval [95\% CI 1.03, 1.31], $P=0.02$ ). Admission to the CCU was more frequent among males than females (odds ratio [OR] 1.38 [95\% CI 1.11, 1.72], $P=0.004)$. There was a nonsignificant trend toward more coronary angiographies performed among males (OR 1.34 [95\% CI 1.00, 1.79], $P=0.05$ ), as well as a nonsignificant trend toward higher 1-year mortality (HR 1.18 [95\% CI 0.99, 1.39], $P=0.06$ ).

Conclusion: In an AMI population aged 75 years and above, males had higher age-adjusted 7 -year mortality and higher rate of admission to the CCU than females. One-year mortality did not differ significantly between the sexes, nor did the frequency of performed coronary angiograms.

Keywords: acute myocardial infarction, elderly patients, characteristics, cardiovascular outcomes, death

\section{Introduction}

In middle-aged populations, differences between males and females are described in terms of various aspects of coronary artery diseases. Males, for example, have a higher rate of previous myocardial infarction (MI). ${ }^{1,2}$ Females, at least in some studies, have been reported to have a longer delay to reach hospital and less frequently to receive invasive therapy for acute myocardial infarction (AMI) than males. ${ }^{3,4}$ In addition, females develop symptomatic cardiovascular disease about a decade later in life than males do. ${ }^{5}$ Age is a demographic predictor of short- and long-term mortality in AMI. ${ }^{6}$ An analysis from the American National Registry of Myocardial Infarction ${ }^{7}$ noted an interaction between sex and age with regard to 30-day mortality. There was a progressive decrease in the difference (higher mortality in females) with increasing age until the age of 75 years. Study results for sex differences in the prevalence of
Correspondence: Nguyen Dang Thang Department of Molecular and

Clinical Medicine, Sahlgrenska University Hospital, Gröna stråket 9 , vån $5 \mathrm{SU} /$ Sahlgrenska, SE-4I 345 ,

Gothenburg, Sweden

Tel +46313427548

Fax +4631827375

Email nguyendangthangvietnam@gmail.com 
and outcome for AMI among patients over 75 years of age have not been described as well as they have been described for middle-aged patients.

Both female sex and increasing age have been reported to be risk factors for atypical symptoms and a less aggressive treatment in AMI. ${ }^{8}$ Therefore, it is of interest to compare females and males when both criteria are fulfilled, that is, to look at sex differences among the elderly patients.

This study analyzed age-adjusted sex differences among AMI patients aged 75 years and above with regard to 7-year mortality (primary end point) and the frequency of angiograms and admission to the coronary care unit (CCU) as well as 1-year mortality (secondary end points).

\section{Patients and methods}

This study was performed at Sahlgrenska University Hospital in Gothenburg. The hospital has facilities for emergency percutaneous coronary intervention at all hours of the week. Gothenburg is the second largest city in Sweden and has 550,000 inhabitants, $7 \%$ of whom are aged 75 years and above. ${ }^{9}$

We collected data during two distinct periods, 2001/2002 and 2007, to evaluate possible changes over time. We have previously described these periods, ${ }^{10}$ and the first period was furthermore described in a comparison between patients living in Minneapolis/St Paul and Gothenburg. ${ }^{11}$

\section{Patients and data collection}

All patients admitted to the Sahlgrenska University Hospital with a final diagnosis of AMI during the two periods (from July 1, 2001 to June 30, 2002 and from January 1, 2007 to December 31, 2007), regardless of whether or not they were admitted to the CCU, were registered. Patients who were residents of Gothenburg and aged 75 years and above were included in this analysis. All data were retrospectively recorded.

A diagnosis of AMI was based on the assessment by the responsible hospital physicians. It was recommended that the diagnosis should be based on a dynamic serial elevation of isoenzyme creatine kinase-MB $>5 \mu \mathrm{g} / \mathrm{L}$ or troponin $\mathrm{T}>0.05 \mu \mathrm{g} / \mathrm{L}$, or an equivalent increase in troponin I plus at least one further criterion (eg, typical chest pain or electrocardiographic signs of acute myocardial ischemia). ${ }^{12-14}$

A 12-lead electrocardiogram (ECG) was recorded on admission to the hospital. The ECG definition of acute myocardial ischemia in the absence of left bundle branch block (LBBB), right bundle branch block, and pacemaker rhythm was ST-segment elevation at the J point in two contiguous leads with the cutoff points of $\geq 1 \mathrm{~mm}(0.1 \mathrm{mV})$ in all leads other than leads V2-V3, where the cutoff points of $\geq 2 \mathrm{~mm}$ $(0.2 \mathrm{mV})$ in males and $\geq 1.5 \mathrm{~mm}(0.15 \mathrm{mV})$ in females applied. In cases of ST-segment depression, the changes regarded as manifestations of acute myocardial ischemia were a downsloping ST segment with a J-point depression of $\geq 0.5 \mathrm{~mm}(0.05 \mathrm{mV})$ in at least two contiguous leads. "Contiguous leads" refer to anterior leads $\left(\mathrm{V}_{1}-\mathrm{V}_{6}\right)$, inferior leads (II, III, aVF), or lateral/apical leads (I, aVL). ${ }^{14}$ When the $\mathrm{V}_{4} \mathrm{R}$ lead was recorded instead of the $\mathrm{V}_{3}$ lead, an ST-segment elevation of $0.5 \mathrm{~mm}(0.05 \mathrm{mV})$ or greater was regarded as a sufficient ECG criterion for acute myocardial ischemia. ${ }^{14}$

In the presence of LBBB, a new LBBB in comparison with the previous ECGs, such as a prehospital ECG, would fulfill the criterion for acute myocardial ischemia. Similarly, if a new ST-segment elevation or a new Q-wave is found in the presence of right bundle branch block, the ECG criteria for acute myocardial ischemia would be fulfilled. ${ }^{14}$

In the event of suspected MI, other investigative cardiac procedures, such as an exercise bicycle test, echocardiography test, and coronary angiography were considered to obtain a final diagnosis. A recurrent MI was considered to be present if the features of AMI started from the 28th day or later following the first incident of AMI and the criteria for acute myocardial ischemia were fulfilled. ${ }^{14} \mathrm{~A}$ reinfarction was considered to be present if an AMI occurred within 28 days of the first incident of AMI or within 28 days of a recurrent MI. ${ }^{14}$

Previous history, smoking habits, ECG records, cardiac treatment procedures, cardiovascular complications, medical treatment, and events after discharge within 1 year of admission to hospital were extracted from the database of the health care system by specially trained monitoring nurses. The date of admission to hospital and the date of discharge from hospital were registered. There was a 7-year follow-up for mortality. The date of death was obtained from the Swedish National Population Register, together with survival confirmation.

\section{Statistical analysis}

All percentages are presented as crude results (ie, not adjusted for age). For comparisons of age between sexes, the MannWhitney $U$-test was used; otherwise $P$-values, including the calculation of odds ratios (ORs) for two of the secondary objectives (admission to the CCU and performance of coronary angiography), were age adjusted using multiple logistic regression. Multiple logistic regression analysis was also used to analyze the interaction between sex and time period. The Kaplan-Meier method was used to estimate mortality, as well as for cardiovascular event rates after hospital discharge. The Cox proportional hazards model was used for age-adjusted $P$-values and time period by sex interaction in terms of 
mortality and event rates and to calculate the hazard ratio (HR) with corresponding 95\% confidence intervals (CIs). For the analysis of mortality and event rates after discharge, only the first admission for those with multiple visits was included. All tests were two-sided, and a $P$-value of $<0.05$ was considered statistically significant for 7-year mortality (primary objective), otherwise a $P$-value of $<0.01$ was required for statistical significance. All analyses were performed using SAS v9.3 software (SAS Institute Inc., Cary, NC, USA). Approval for this study was given by the Research Ethics Committee at Gothenburg University, Guldhedsgatan 5A, SE-413 20 Gothenburg, Sweden. This study was retrospective and the Research Ethics Committee at Gothenburg University deemed informed consent not necessary.

\section{Results}

In total, there were 1,414 elderly patients with a final diagnosis of AMI in both periods (2001/2002 and 2007), including $748(53 \%)$ females and $666(47 \%)$ males. The distribution of sexes was similar in the two periods.

\section{Baseline characteristics and admission to $\mathrm{CCU}$}

Females were older and had a lower prevalence of previous AMI and coronary artery bypass grafting $(\mathrm{CABG})$ but a higher prevalence of diagnosed hypertension. A history of renal disease was more common among males, more so in 2001/2002 than in 2007. Males were admitted to the CCU (secondary end point) more frequently than females, ageadjusted OR for males vs females was 1.38 (95\% CI 1.11, $1.72, P=0.004)$. The duration of hospital stay was similar in both females and males (Table 1).

\section{Symptoms, ECG, cardiovascular events, and treatment in hospital}

The proportion of patients with symptoms of chest pain, cardiogenic shock, and congestive heart failure on admission to hospital did not differ significantly between females and males (Table 2).

Sixty-five percent of the patients had an ECG recorded on admission to the hospital. Among them, ST-segment elevation, especially with a location in the anterior leads, occurred more frequently in females, while LBBB was more frequent in males.

There was no statistically significant difference for the secondary end point of coronary angiography, and ageadjusted OR for males vs females was 1.34 (95\% CI 1.00, $1.79, P=0.05$ ) (Table 3 ). The proportions of females and males who underwent other cardiac procedures, including reperfusion therapy, did not differ significantly, except for

Table I Baseline characteristics of the elderly patients with AMI

\begin{tabular}{|c|c|c|c|c|c|c|c|c|}
\hline \multirow[t]{2}{*}{ Characteristics } & \multicolumn{2}{|c|}{$2001 / 2002$} & \multicolumn{2}{|l|}{2007} & \multicolumn{2}{|c|}{$2001 / 2002+2007$} & \multirow[t]{2}{*}{$P$-value ${ }^{a}$} & \multirow[t]{2}{*}{$P$-value ${ }^{b}$} \\
\hline & $\begin{array}{l}\text { Females } \\
(n=4 \mid 6)\end{array}$ & $\begin{array}{l}\text { Males } \\
(n=387)\end{array}$ & $\begin{array}{l}\text { Females } \\
(n=332)\end{array}$ & $\begin{array}{l}\text { Males } \\
(n=279)\end{array}$ & $\begin{array}{l}\text { Females } \\
(n=748)\end{array}$ & $\begin{array}{l}\text { Males } \\
(n=666)\end{array}$ & & \\
\hline Age (mean $\pm S D$; years) & $84 \pm 5$ & $83 \pm 5$ & $85 \pm 5$ & $83 \pm 5$ & $84 \pm 5$ & $83 \pm 5$ & $<0.0001$ & 0.49 \\
\hline \multicolumn{9}{|l|}{ Previous medical history (\%) } \\
\hline AMI & 35 & $50^{c}$ & 42 & $43^{c}$ & 38 & $47^{c}$ & 0.0001 & 0.01 \\
\hline CABG & 6 & 10 & 8 & $18^{c}$ & 7 & 13 & 0.001 & 0.21 \\
\hline $\mathrm{PCl}$ & 3 & 3 & $\mathrm{II}$ & $9^{c}$ & 7 & 6 & 0.16 & 0.75 \\
\hline Angina pectoris & $46^{c}$ & $48^{c}$ & $28^{c}$ & $35^{c}$ & $38^{c}$ & $42^{c}$ & 0.04 & 0.21 \\
\hline Cardiac arrest & $<1$ & 2 & 0 & $0^{c}$ & $<1$ & $<1$ & 0.51 & 1.00 \\
\hline Congestive heart failure & 38 & 44 & 33 & 26 & 36 & 36 & 0.27 & 0.01 \\
\hline Atrial fibrillation & 23 & 30 & 27 & $24^{c}$ & 25 & 28 & 0.07 & 0.04 \\
\hline Hypertension & 58 & 51 & $60^{c}$ & $53^{c}$ & $59^{c}$ & $53^{c}$ & 0.004 & 0.93 \\
\hline Cerebrovascular disease & 25 & 22 & 23 & 19 & 24 & 21 & 0.12 & 0.76 \\
\hline Peripheral vascular disease & $12^{c}$ & 18 & 12 & 13 & 12 & 16 & 0.07 & 0.20 \\
\hline Diabetes & 20 & 22 & 28 & 25 & 23 & 23 & 0.53 & 0.19 \\
\hline Renal disease & $3^{c}$ & 15 & $\mathrm{II}$ & 12 & 7 & 13 & $<0.0001$ & 0.0001 \\
\hline COPD & 11 & 12 & 13 & $12^{c}$ & 12 & 12 & 0.75 & 0.32 \\
\hline Connective tissue disease & 4 & 2 & 0 & 0 & 2 & 1 & 0.23 & 1.00 \\
\hline Cancer & $4^{c}$ & $8^{c}$ & 10 & 12 & 7 & 9 & 0.08 & 0.27 \\
\hline Current smoking (\%) & $9^{e}$ & $12^{d}$ & $8^{c}$ & $8^{c}$ & $8^{d}$ & $10^{c}$ & 0.65 & 0.40 \\
\hline Admitted to CCU (\%) & 39 & 53 & 34 & 38 & 36 & 47 & 0.004 & 0.04 \\
\hline Duration of hospital stay (days) & 6 & 7 & 6 & 5 & 6 & 6 & 0.75 & 0.32 \\
\hline
\end{tabular}

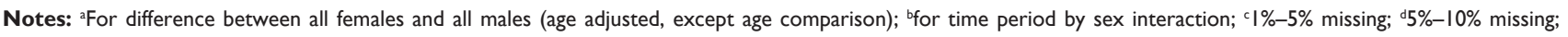
e $10 \%-25 \%$ missing.

Abbreviations: AMI, acute myocardial infarction; CABG, coronary artery bypass grafting; PCl, percutaneous coronary intervention; COPD, chronic obstructive pulmonary disease; CCU, coronary care unit. 
Table 2 Clinical symptoms and ECG findings (\%)

\begin{tabular}{|c|c|c|c|c|c|c|c|c|}
\hline \multirow[t]{2}{*}{ Characteristics } & \multicolumn{2}{|c|}{$2001 / 2002$} & \multicolumn{2}{|l|}{2007} & \multicolumn{2}{|c|}{$2001 / 2002+2007$} & \multirow[t]{2}{*}{$P$-value ${ }^{a}$} & \multirow[t]{2}{*}{$P$-value } \\
\hline & $\begin{array}{l}\text { Females } \\
(n=4 \mid 6)\end{array}$ & $\begin{array}{l}\text { Males } \\
(n=387)\end{array}$ & $\begin{array}{l}\text { Females } \\
(n=332)\end{array}$ & $\begin{array}{l}\text { Males } \\
(n=279)\end{array}$ & $\begin{array}{l}\text { Females } \\
(n=748)\end{array}$ & $\begin{array}{l}\text { Males } \\
(n=666)\end{array}$ & & \\
\hline \multicolumn{9}{|l|}{ Clinical symptoms } \\
\hline Chest pain/pressure/discomfort & $80^{c}$ & $86^{c}$ & $73^{c}$ & $74^{c}$ & $77^{c}$ & $8 I^{c}$ & 0.04 & 0.22 \\
\hline Pulmonary edema or cardiogenic shock & 6 & $8^{c}$ & 9 & 9 & 8 & 8 & 0.60 & 0.47 \\
\hline Congestive heart failure & 43 & 41 & $5 I^{c}$ & $40^{c}$ & $46^{c}$ & 40 & 0.14 & 0.14 \\
\hline ECG recording available ${ }^{d}$ & 49 & 50 & 84 & 85 & 65 & 65 & 0.82 & 0.88 \\
\hline ST elevation & 15 & 9 & 15 & 8 & 15 & 9 & 0.004 & 0.90 \\
\hline \multicolumn{9}{|l|}{ Location } \\
\hline Anterior & 13 & 7 & 12 & 5 & 12 & 6 & 0.0009 & 0.59 \\
\hline Inferior & 4 & 3 & 5 & 4 & 5 & 3 & 0.25 & 0.64 \\
\hline Lateral & $<1$ & $<1$ & I & 0 & $<1$ & $<1$ & 0.37 & 0.41 \\
\hline ST depression & 35 & 20 & 28 & 26 & 31 & 23 & 0.02 & 0.02 \\
\hline LBBB & 9 & 19 & 10 & 18 & 10 & 18 & 0.0003 & 0.59 \\
\hline Other pathological ECG changes & 50 & 53 & 41 & 49 & 45 & 51 & 0.09 & 0.43 \\
\hline Sinus rhythm & 72 & 68 & 72 & 67 & 72 & 68 & 0.07 & 0.97 \\
\hline Normal ECG & 24 & 21 & 29 & 22 & 27 & 22 & 0.08 & 0.52 \\
\hline
\end{tabular}

Notes: ${ }^{a}$ For difference between all females and all males (age adjusted); ${ }^{\text {for }}$ time period by sex interaction; ${ }^{\mathrm{c}} \% \mathrm{\%} \%$ missing; ${ }^{\mathrm{d}}$ refers to patients with available ECG recordings.

Abbreviations: ECG, electrocardiogram; LBBB, left bundle branch block.

Table 3 Cardiac procedures, reperfusion therapy, complications, and death during hospitalization (\%)

\begin{tabular}{|c|c|c|c|c|c|c|c|c|}
\hline \multirow{2}{*}{$\begin{array}{l}\text { Procedures and } \\
\text { complications }\end{array}$} & \multicolumn{2}{|c|}{$2001 / 2002$} & \multicolumn{2}{|l|}{2007} & \multicolumn{2}{|c|}{$2001 / 2002+2007$} & \multirow[t]{2}{*}{$P$-value ${ }^{a}$} & \multirow[t]{2}{*}{$P$-value } \\
\hline & $\begin{array}{l}\text { Females } \\
(n=4 \mid 6)\end{array}$ & $\begin{array}{l}\text { Males } \\
(n=387)\end{array}$ & $\begin{array}{l}\text { Females } \\
(n=332)\end{array}$ & $\begin{array}{l}\text { Males } \\
(n=279)\end{array}$ & $\begin{array}{l}\text { Females } \\
(n=748)\end{array}$ & $\begin{array}{l}\text { Males } \\
(n=666)\end{array}$ & & \\
\hline \multicolumn{9}{|l|}{ Cardiac procedures } \\
\hline Exercise bicycle test & 5 & II & 2 & $2^{c}$ & 4 & 7 & 0.04 & 0.09 \\
\hline Echocardiography & 33 & 42 & 31 & 42 & 32 & 42 & 0.02 & 0.78 \\
\hline Coronary angiography & 9 & 15 & 20 & 29 & 14 & 21 & 0.05 & 0.70 \\
\hline \multicolumn{9}{|l|}{ Reperfusion therapy } \\
\hline Thrombolysis & 6 & 5 & $<1$ & 0 & 3 & 3 & 0.52 & 0.91 \\
\hline $\mathrm{PCl}$ & 5 & 5 & 14 & 22 & 9 & 12 & 0.31 & 0.23 \\
\hline Rescue & 1 & $<1$ & 0 & 0 & $<1$ & $<1$ & 0.45 & 1.00 \\
\hline Primary & 4 & 4 & 12 & 20 & 7 & 11 & 0.14 & 0.34 \\
\hline Elective & $<1$ & 0 & 2 & 2 & 1 & $<1$ & 0.44 & 1.00 \\
\hline CABG & 1 & 6 & 2 & 3 & 1 & 4 & 0.007 & 0.14 \\
\hline \multicolumn{9}{|l|}{ Complications } \\
\hline Reinfarction & 2 & $4^{c}$ & 2 & 3 & 2 & 4 & 0.01 & 0.65 \\
\hline Cardiogenic shock & 2 & $3^{c}$ & 2 & 3 & 2 & $3^{c}$ & 0.55 & 0.94 \\
\hline Hemorrhage requiring transfusion & 2 & $5^{c}$ & 5 & 5 & 3 & $5^{c}$ & 0.07 & 0.11 \\
\hline Hypotension & 11 & $15^{c}$ & 17 & 16 & 14 & $15^{\mathrm{c}}$ & 0.43 & 0.07 \\
\hline Pulmonary embolism & $<1$ & $<I^{c}$ & 2 & I & I & $<I^{c}$ & 0.45 & 1.00 \\
\hline Stroke & 7 & $4^{c}$ & 2 & 4 & 5 & $4^{c}$ & 0.45 & 0.03 \\
\hline Deep vein thrombosis & $<1$ & $I^{c}$ & 0 & $<1$ & $<1$ & $<I^{c}$ & 0.06 & 1.00 \\
\hline Congestive heart failure & 51 & $5 I^{c}$ & 19 & 15 & 37 & 36 & 0.95 & 0.25 \\
\hline Acute renal failure & 3 & $5^{c}$ & 2 & 2 & 3 & $4^{c}$ & 0.18 & 0.29 \\
\hline Pneumonia & 8 & $14^{\mathrm{c}}$ & 7 & 7 & 8 & $I I^{c}$ & 0.03 & 0.21 \\
\hline Pericarditis & 0 & $<\mathrm{I}^{\mathrm{c}}$ & 0 & $<1$ & 0 & $<\mathrm{I}^{\mathrm{c}}$ & 0.51 & 1.00 \\
\hline Death & 17 & 20 & 20 & 16 & 18 & 18 & 0.73 & 0.12 \\
\hline
\end{tabular}

Notes: ${ }^{\text {a}}$ For difference between all females and all males (age adjusted); ${ }^{b}$ for time period by sex interaction; ${ }^{\mathrm{c}} \mathrm{l} \%-5 \%$ missing.

Abbreviations: AMI, acute myocardial infarction; $\mathrm{PCl}$, percutaneous coronary intervention; CABG, coronary artery bypass grafting. 
Table 4 Medication at discharge (of those discharged alive [\%])

\begin{tabular}{|c|c|c|c|c|c|c|c|c|}
\hline \multirow[t]{2}{*}{ Medication } & \multicolumn{2}{|c|}{$2001 / 2002$} & \multicolumn{2}{|l|}{2007} & \multicolumn{2}{|c|}{$2001 / 2002+2007$} & \multirow[t]{2}{*}{$P$-value ${ }^{a}$} & \multirow[t]{2}{*}{$P$-value ${ }^{b}$} \\
\hline & $\begin{array}{l}\text { Females } \\
(n=345)\end{array}$ & $\begin{array}{l}\text { Males } \\
(n=3 \mid 0)\end{array}$ & $\begin{array}{l}\text { Females } \\
(n=267)\end{array}$ & $\begin{array}{l}\text { Males } \\
(n=235)\end{array}$ & $\begin{array}{l}\text { Females } \\
(n=6 \mid 2)\end{array}$ & $\begin{array}{l}\text { Males } \\
(n=545)\end{array}$ & & \\
\hline Anticoagulants & 12 & 14 & 14 & 19 & 13 & 16 & 0.15 & 0.70 \\
\hline Aspirin & 84 & 83 & 79 & 83 & 82 & 83 & 0.51 & 0.23 \\
\hline Nitrates & 42 & 45 & 62 & 66 & 51 & 54 & 0.15 & 0.95 \\
\hline Digitalis & 16 & 13 & 11 & 7 & 14 & 10 & 0.06 & 0.53 \\
\hline Diuretics & 68 & 66 & 66 & 58 & 67 & 63 & 0.34 & 0.19 \\
\hline Beta-blockers & 85 & 82 & 82 & 85 & 84 & 83 & 0.52 & 0.11 \\
\hline Calcium channel blockers & 15 & 15 & 14 & 14 & 15 & 15 & 0.77 & 0.82 \\
\hline ACE inhibitors/A2-blockers & 34 & 40 & 38 & 41 & 36 & 41 & 0.18 & 0.52 \\
\hline Lipid-lowering agents & 22 & 32 & 49 & 58 & 34 & 43 & 0.04 & 0.38 \\
\hline
\end{tabular}

Notes: aFor difference between all females and all males (age adjusted); bfor time period by sex interaction.

Abbreviation: ACE, angiotensin-converting enzyme.

CABG, which was performed significantly more frequently in males (Table 3).

Table 3 also shows that there was no significant difference in the frequency of various complications in relation to AMI between males and females.

\section{Medication at discharge}

There was no statistically significant difference between females and males with regard to medication at discharge from hospital (Table 4).

\section{Outcomes in hospital and during follow-up}

Of all the patients, $18 \%$ died during hospitalization in both sex groups (Table 3).

Among the patients who were alive at discharge from hospital, $29 \%$ of females and $33 \%$ of males died within 1 year of their index admission (Table 5). There were no statistically significant differences regarding AMI or stroke after hospital discharge between males and females during 1 year after index admission.

The 7 -year mortality rate was above $80 \%$ for both males and females during both time periods (Figure 1), although there was a statistically significant difference between the sexes for this parameter (the primary end point) when adjusting for age, with an HR (males vs females) of 1.16 (95\% CI 1.03, 1.31, $P=0.02$ ). For the two separate time periods, the HR was 1.20 (95\% CI 1.02, 1.41, $P=0.02$ ) in 2001/2002 and $1.12(95 \%$ CI $0.93,1.35, P=0.23)$ in 2007.

For death during the first year following index AMI admission including in-hospital mortality (secondary objective), there was a nonsignificant trend toward higher mortality among males than females, with an age-adjusted HR of 1.18 ( $95 \%$ CI $0.99,1.39, P=0.06)$. When adjusting also for all previous history variables (Table 1), HR for 7-year mortality was 1.13 (95\% CI $0.99,1.30, P=0.07)$, and HR for 1-year mortality was 1.11 (95\% CI 0.92 , $1.34, P=0.28)$.

Table 5 Cardiovascular events and death after hospital discharge within I year of admission to the hospital (of those discharged alive, only first admission included [\%])

\begin{tabular}{|c|c|c|c|c|c|c|c|c|}
\hline \multirow{2}{*}{$\begin{array}{l}\text { Cardiovascular events } \\
\text { and deaths }\end{array}$} & \multicolumn{2}{|c|}{$2001 / 2002$} & \multicolumn{2}{|l|}{2007} & \multicolumn{2}{|c|}{$2001 / 2002+2007$} & \multirow[t]{2}{*}{$P$-value ${ }^{a}$} & \multirow[t]{2}{*}{$P$-value } \\
\hline & $\begin{array}{l}\text { Females } \\
(n=323)\end{array}$ & $\begin{array}{l}\text { Males } \\
(\mathrm{n}=\mathbf{2 7 8})\end{array}$ & $\begin{array}{l}\text { Females } \\
(n=243)\end{array}$ & $\begin{array}{l}\text { Males } \\
(n=215)\end{array}$ & $\begin{array}{l}\text { Females } \\
(n=566)\end{array}$ & $\begin{array}{l}\text { Males } \\
(n=493)\end{array}$ & & \\
\hline Recurrent myocardial infarction & $14^{c}$ & 24 & 17 & 16 & $15^{c}$ & 21 & 0.03 & 0.03 \\
\hline Coronary angiography & $4^{c}$ & 7 & $3^{c}$ & 6 & $4^{c}$ & 7 & 0.17 & 0.72 \\
\hline $\mathrm{PCl}$ & $2^{c}$ & 3 & $I^{c}$ & 3 & $2^{c}$ & 3 & 0.56 & 0.40 \\
\hline CABG & $I^{c}$ & 5 & $<\mathrm{I}^{\mathrm{c}}$ & 1 & $<\mathrm{I}^{\mathrm{c}}$ & 4 & 0.02 & 0.54 \\
\hline Stroke & $6^{c}$ & 4 & $I^{c}$ & $<1$ & $4^{c}$ & 2 & 0.12 & 0.64 \\
\hline Death & 28 & 32 & 31 & 33 & 29 & 33 & 0.02 & 0.55 \\
\hline
\end{tabular}

Notes: a For difference between all females and all males (age adjusted); ${ }^{b}$ for time period by sex interaction; ${ }^{c} \mathrm{I} \%-5 \%$ missing.

Abbreviations: $\mathrm{PCl}$, percutaneous coronary intervention; $\mathrm{CABG}$, coronary artery bypass grafting. 


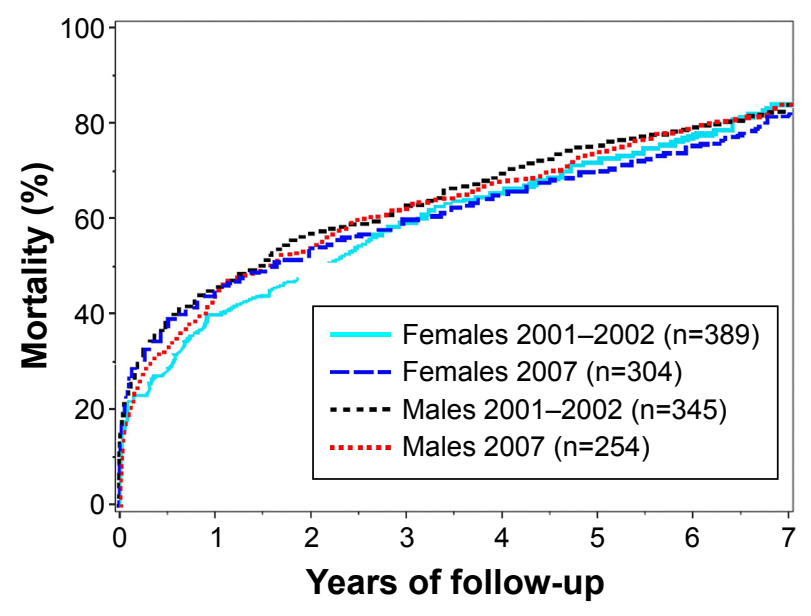

Figure I Cumulative mortality during 7 years of follow-up.

\section{Discussion}

This study is a comparison between females and males over the age of 75 years with regard to the diagnosis of AMI and survival follow-up data of all patients for more than 7 years. The primary end point was mortality after 7 years, and during that period, the mortality was as high as above $80 \%$ for both sexes. Males had higher age-adjusted 7-year mortality than females. For one of the secondary end points, that is, mortality (including in-hospital mortality) during 1 year, there was no statistically significant difference between the sexes. Previous surveys have shown higher mortality in females in both short- and long-term outcomes, ${ }^{15,16}$ which differs from our results in this respect and the explanation is not clear.

Males showed a significantly higher admission rate to the CCU than females. Similar findings were reported in previous studies. ${ }^{17}$ The reason behind this finding is not known, but it has even been discussed in terms of inappropriate sex bias. Age, previous MI and/or CABG, and clinical symptoms seem to be the factors predicting the initial degree of suspicion of AMI. ${ }^{18}$ In our study, when adjusting for age and previous $\mathrm{MI}$ and/or CABG, rate of CCU admission was still significantly higher in males than females (OR 1.38 [95\% CI 1.10, 1.72]). We speculated that a higher prevalence of clinical severity in males than in females might be the main reason. Unfortunately, the registrations were not available to us to test this hypothesis.

Some of the previous studies showed a lower rate of invasive therapy for AMI among females when compared with males, ${ }^{19}$ but others reported the opposite results. ${ }^{20}$ In our study, CABG was performed more frequently in males than in females. The reason for this finding might be that extensive coronary artery disease is more frequent in males than in females. ${ }^{21} \mathrm{~A}$ higher rate of previous MI or CABG and the more frequent presence of LBBB might also indicate more extensive coronary artery disease in males. We did not find significant sex differences in any other indices of potential revascularization. The use of coronary angiography was one of our secondary end points for which there was no statistically significant difference between the sexes (age-adjusted OR 1.34 [95\% CI 1.00, 1.79]).

Other aspects of therapy, such as medication at discharge from hospital, did not differ between the sexes, in line with previous reporting. ${ }^{22}$ Other studies have reported that betablockers and angiotensin-converting enzyme inhibitors were used more frequently in males than in females. ${ }^{23}$ Both these medicines have been shown to reduce mortality in AMI patients. ${ }^{24}$

In this study population, females were older than males and had a lower prevalence of previous MI. Our findings are in agreement with those reported in the literature. ${ }^{23,25}$

In a population of young patients with previous AMI, a higher prevalence of hypertension was found in males. However, in those over 40 years of age, opposite results were found. ${ }^{15}$ In our study, females had a higher prevalence of previous hypertension, which is in agreement with that reported by other studies. ${ }^{15,23,25}$

Previous studies have suggested that, for anatomic reasons, ST-elevation myocardial infarction (STEMI) is less frequent in females than in males. ${ }^{26}$ In our region, the Västra Götaland region of Sweden, a study in 2008 of unselected patients with AMI found a similar degree of ST deviation in both sexes. ${ }^{25}$ In the present study, STEMI was more frequent in females than in males. The mechanism behind this observation is unclear. We speculate that AMIs in elderly patients might differ from those in younger patients. ${ }^{27}$ However, a lack of availability of ECGs recorded on admission to hospital in both study periods might have influenced this finding. There was a lower prevalence of LBBB in females, which is in agreement with the previous observations. ${ }^{23,25}$

\section{Strengths and limitations of the study}

The main strength of this study is that all elderly patients hospitalized with an AMI in a certain catchment area were included and followed for a long period, with 7-year mortality data for all patients.

Furthermore, the study population is unselected and has a high degree of representativeness, as all patients with a final diagnosis of AMI were included, regardless of whether or not they were admitted to the CCU. The date of death was obtained from the Swedish National Population 
Register, which has a high degree of quality control and high validity.

One limitation of this study was the retrospective collection of data. As a result, some information was missing. The availability of ECGs registered in the emergency room on admission was low in the first study period. This might influence the ECG findings and limit our opportunity to draw the correct conclusions. We presume that prehospital ECGs and ECGs monitored during ambulance transport were used instead of ECGs recorded in the emergency department. ${ }^{28}$ Unfortunately, these registrations were not available to us.

Another limitation was that the AMI diagnosis was based on the official clinical judgment and not on study-specific criteria. On the other hand, this reflects the real-world situation. We also lacked information about the causes of death during follow-up.

Finally, patients were recruited some years ago, and treatment routines for AMI differ in some respects today as compared with the time of the surveys.

\section{Conclusion}

In this study population, males had higher age-adjusted 7-year mortality and higher rate of admission to the CCU than females. One-year mortality did not differ significantly between females and males, nor did the frequency of performed coronary angiograms.

The mortality was high for both sexes, both in the first year and during the 7-year follow-up. From our results, there seems to be room for improvement at all levels of care for these elderly patients. This includes providing initial CCU treatment, invasive investigations, revascularization procedures, and medication.

Basically, these elderly patients should be treated according to the guideline ${ }^{29-31}$ to a maximum extent possible, while keeping in mind their individual needs.

\section{Disclosure}

Björn W Karlson is an employee of AstraZeneca. The other authors report no conflicts of interest in this work.

\section{References}

1. Hansen KW, Soerensen R, Madsen M, et al. Developments in the invasive diagnostic-therapeutic cascade of women and men with acute coronary syndromes from 2005 to 2011: a nationwide cohort study. BMJ Open. 2015;5(6):e007785.

2. Kalyani RR, Lazo M, Ouyang P, et al. Sex differences in diabetes and risk of incident coronary artery disease in healthy young and middle-aged adults. Diabetes Care. 2014;37(3):830-838.

3. Lefler LL, Bondy KN. Women's delay in seeking treatment with myocardial infarction: a meta-synthesis. J Cardiovasc Nurs. 2004;19(4): 251-268.
4. Fang J, Alderman MH. Gender differences of revascularization in patients with acute myocardial infarction. Am J Cardiol. 2006;97(12): 1722-1726.

5. Simon T, Puymirat E, Lucke V, et al. L'infarctus du myocarde chez la femme. Caractéristiques spécifiques, prise en charge et pronostic. Données de FAST-MI 2010. [Acute myocardial infarction in women. Initial characteristics, management and early outcome. The FAST-MI registry]. Ann Cardiol Angeiol (Paris). 2013;62(4):221-226. French.

6. Karlson BW, Lindqvist J, Sjolin M, Caidahl K, Herlitz J. Which factors determine the long-term outcome among patients with a very small or unconfirmed AMI. Int J Cardiol. 2001;78(3):265-275.

7. Berger JS, Brown DL. Gender-age interaction in early mortality following primary angioplasty for acute myocardial infarction. Am J Cardiol. 2006;98(9):1140-1143.

8. Puddu PE, Terradura-Vagnarelli O, Mancini M, Zanchetti A, Menotti A. Typical and atypical coronary heart disease deaths and their different relationships with risk factors. The Gubbio residential cohort study. Int J Cardiol. 2014;173(2):300-304.

9. Göteborg stad [homepage on the Internet]. Äldrebladet 2015 [updated December 31, 2015; cited January 8, 2016]. Available from: http:// www4.goteborg.se/prod/G-info/statistik.nsf/34f4087fac810b1ac1256 cdf003efa4b/5cfc5d5de8805038c1257f5c0037a40b!OpenDocument. Accessed April 6, 2016.

10. Libungan B, Karlsson T, Albertsson P, Herlitz J. Elderly patients with myocardial infarction selected for conservative or invasive treatment strategy. Clin Interv Aging. 2015;10:321-327.

11. Smith LG, Herlitz J, Karlsson T, Berger AK, Luepker RV. International comparison of treatment and long-term outcomes for acute myocardial infarction in the elderly: Minneapolis/St. Paul, MN, USA and Goteborg, Sweden. Eur Heart J. 2013;34(41):3191-3197.

12. Herlitz J, Dellborg M, Karlsson T, Evander MH, Berger A, Luepker R. Epidemiology of acute myocardial infarction with the emphasis on patients who did not reach the coronary care unit and non-AMI admissions. Int J Cardiol. 2008;128(3):342-349.

13. Hermsen D, Apple F, Garcia-Beltran L, et al. Results from a multicenter evaluation of the 4 th generation Elecsys Troponin T assay. Clin Lab. 2007;53(1-2):1-9.

14. Thygesen K, Alpert SJ, Jaffe SA, et al. Third universal definition of myocardial infarction. Eur Heart J. 2012;33(20):2551-2567.

15. Gupta A, Wang Y, Spertus JA, et al. Trends in acute myocardial infarction in young patients and differences by sex and race, 2001 to 2010. J Am Coll Cardiol. 2014;64(4):337-345.

16. Koek HL, de Bruin A, Gast F, et al. Short- and long-term prognosis after acute myocardial infarction in men versus women. Am J Cardiol. 2006;98(8):993-999.

17. Herlitz J, Karlson BW, Karlsson T, Svensson L, Bjorn Kalin EZ. A description of the characteristics and outcome of patients hospitalized for acute chest pain in relation to whether they were admitted to the coronary care unit or not in the thrombolytic era. Int J Cardiol. 2002;82(3):279-287.

18. Karlson BW, Herlitz J, Wiklund O, Richter A, Hjalmarson A. Early prediction of acute myocardial infarction from clinical history, examination and electrocardiogram in the emergency room. Am J Cardiol. 1991; 68(2):171-175.

19. Rathore SS, Foody JM, Radford MJ, Krumholz HM. Sex differences in use of coronary revascularization in elderly patients after acute myocardial infarction: a tale of two therapies. Chest. 2003;124(6): 2079-2086.

20. Heer T, Hochadel M, Schmidt K, et al. Gender differences in therapeutic recommendation after diagnostic coronary angiography: insights from the Coronary Angiography and PCI Registry of the German Society of Cardiology. Clin Res Cardiol. 2015;104(6):507-517.

21. Kyriakidis M, Petropoulakis $P$, Androulakis A, et al. Sex differences in the anatomy of coronary artery disease. J Clin Epidemiol. 1995;48(6): 723-730.

22. Jelinski SE, Ghali WA, Parsons GA, Maxwell CJ. Absence of sex differences in pharmacotherapy for acute myocardial infarction. Can J Cardiol. 2004;20(9):899-905. 
23. Redfors B, Angerås O, Råmunddal T, et al. Trends in gender differences in cardiac care and outcome after acute myocardial infarction in Western Sweden: a report from the Swedish Web System for Enhancement of Evidence-Based Care in Heart Disease Evaluated According to Recommended Therapies (SWEDEHEART). J Am Heart Assoc. 2015;4(7): pii:e001995.

24. Konishi M, Haraguchi G, Yoshikawa S, Kimura S, Inagaki H, Isobe M. Additive effects of $\beta$-blockers on renin-angiotensin system inhibitors for patients after acute myocardial infarction treated with primary coronary revascularization. Circ J. 2011;75(8):1982-1991.

25. Herlitz J, Dellborg M, Karlsson T, et al. Treatment and outcome in acute myocardial infarction in a community in relation to gender. Int $J$ Cardiol. 2009;135(3):315-322.

26. Jneid H, Fonarow GC, Cannon CP, et al. Sex differences in medical care and early death after acute myocardial infarction. Circulation. 2008;118(25):2803-2810.

27. Woon VC, Lim KH. Acute myocardial infarction in the elderly - the differences compared with the young. Singapore Med J. 2003;44(8): 414-418.
28. Rushworth GF, Bloe C, Diack HL, et al. Pre-hospital ECG E-transmission for patients with suspected myocardial infarction in the highlands of Scotland. Int J Environ Res Public Health. 2014;11(2):2346-2360.

29. Steg PG, James SK, Atar D, et al. ESC guidelines for the management of acute myocardial infarction in patients presenting with ST-segment elevation. Task Force on the management of ST-segment elevation acute myocardial infarction of the European Society of Cardiology (ESC). Eur Heart J. 2012;33(20):2569-2619. Epub 2012 Aug 24.

30. Hamm CW, Bassand JP, Agewall S, et al. ESC guidelines for the management of acute coronary syndromes in patients presenting without persistent ST-segment elevation: The Task Force for the management of acute coronary syndromes (ACS) in patients presenting without persistent ST-segment elevation of the European Society of Cardiology (ESC). Eur Heart J. 2011;32(23):2999-3054. Epub 2011 Aug 26.

31. O'Gara PT, Kushner FG, Ascheim DD, et al. 2013 ACCF/AHA guideline for the management of ST-elevation myocardial infarction: a report of the American College of Cardiology Foundation/American Heart Association Task Force on Practice Guidelines. Circulation. 2013;127(4):362-425. Epub 2012 Dec 17.
Clinical Interventions in Aging

\section{Publish your work in this journal}

Clinical Interventions in Aging is an international, peer-reviewed journal focusing on evidence-based reports on the value or lack thereof of treatments intended to prevent or delay the onset of maladaptive correlates of aging in human beings. This journal is indexed on PubMed Central, MedLine,

\section{Dovepress}

CAS, Scopus and the Elsevier Bibliographic databases. The manuscript management system is completely online and includes a very quick and fair peer-review system, which is all easy to use. Visit http://www.dovepress. com/testimonials.php to read real quotes from published authors. 